\title{
The Effect of Client-centered Sandplay Therapy on the Depression, Aggression and Ego Development Stage of Children in a Community Child Center
}

\author{
Soo Kyung Kwak*
}

\author{
Mia Seo**
}

\begin{abstract}
$<$ Abstract $>$
The purpose of this study was to examine the effect of client-centered sandplay therapy on the depression, aggression, and ego development stage of children at a community child center. A total of 12 sessions of client-centered sandplay therapy was conducted with 11 children. The Mann-Whitney $U$ test was used for the homogeneity test, and the Wilcoxon signed rank test was used to verify the differences between the pretest and posttest data. The depression and aggression in SCT and HTP were examined and the statements of the children and social workers concerned were reviewed. The aspects of Kalff's ego development stage were also analyzed. The results of the study are as follows: the depression of those who participated in the program was significantly reduced; the aggression was also significantly reduced; the children underwent three levels of ego development stage in order, and each child had a distinctive launching level and speed while undergoing the ego development stage. This study yielded evidence that the client-centered sandplay therapy was effective for children who suffered from depression or aggression.
\end{abstract}

Keywords : client-centered sandplay therapy, children in community child centers, depression, aggression, ego development stage

* Master's in Counseling at General Graduate School at Dankook University

** Corresponding author, Professor of Counseling at Dankook University (miaseo@dankook.ac.kr) 
Journal of Symbols \& Sandplay Therapy, Vol.9 No.2.

\section{I . Introduction}

Depression and aggression, which are classified as typical symptoms of internalizing problems and externalizing problems respectively by Achenbach (1991), are highly serious as they may not only impact a child's whole life but also extend to social problems. Critical emotional elements involved with depression may lead the child to experience frustrations and failures in daily life, develop a lack of trust in oneself, and form a negative ego-concept, thereby greatly impacting the child's overall development and cause serious adaptation-related issues (Kim, 2008). Childhood depression may be manifested in the form of emotional and behavioral disorders, lack of social skills and poor academic performance during adolescence. It may even extend to one's adulthood, in which the depression is displayed in the form of criminal behavior, drug and alcohol abuse, and so on (Kwon, 2013). At the same time, however, study findings have confirmed that children have a higher rate of success in terms of depression treatment than adults. In other words, there does exist a "golden timing" for child depression treatment. While $80 \%$ of children with depression can be treated completely, around $25-50 \%$ of adults experience symptoms returning within 2 years after recovering from the last episode (Lee, 2005; as cited in Lee, 2015). Therefore, timely intervention is highly necessary for childhood depression, as treatment success rate is much higher in one's childhood than in adulthood. In case of aggression displayed by children, such behavior is displayed consistently throughout one's childhood and adolescence and therefore is often regarded as a general characteristic of childhood. But one's aggression displayed in childhood extend to adolescence and later stages in life, which means that it not only affects the individual but is also closely related to social problems such as school violence. Thus, appropriate intervention is necessary.

Considering the different characteristics of depression or aggression experienced by a child from those experienced by an adult, a timely intervention is necessary. In a society when family functioning is impaired with regards to childcare, however, it has become difficult to hold only the family accountable for recognizing the child's emotional problems and making a decision on a possible therapeutic intervention. Thus the government has laid out policies to resolve problems caused by impaired family functioning. Examples of services for children and 
adolescents provided through those policies are as follows: Wee Class at schools, Ministry of Education's after school care classes, Ministry of Gender Equality and Family's health family support centers, Community Youth Safety-Net for youth counseling, and Ministry of Health and Welfare's community child centers. Among them, community child centers provide comprehensive welfare services including protection, education, culture, emotional support and community support with an aim to reinforce family functioning. As of December 2016, 106,668 children use the services provided by 4,107 community child centers across the country. Among these children, more than $80 \%$ are children from dual-earner households, families who depend on the national basic livelihood security system, multi-cultural families and grandparent families. One of the services offered by community child centers is to have the community provide counseling service to children in need. These services are usually offered through the support of national counseling organizations and community volunteer organizations for free or at a price lower than that of private counseling agencies.

In addition, many studies related to children's emotional problems, including depression and aggression, are being conducted in a bid to find the right type of intervention. Studies on children's depression found that cognitive behavioral education program (Kim, 2008) and self-confrontation program (Sohn, 2011) have positive effects in improving children's depression. The study of Choi (2017) found that art therapy reduced depression in children from divorced families. Yoon (2009) confirmed that group game play therapy improves children's depression level. Moreover, there are also multiple researches done on children's aggression. Group cognitive behavioral therapy (Nam \& Baek, 2013) and group verbal therapy (Lim \& Kim, 2010) had reduced aggression of elementary school children. There was also a study in which group forgiveness program had positive effect on the aggression of sixth-year elementary school students (Kim \& Lee, 2012). The study of Seo (2013) also discovered that an eight-year-old child who showed symptoms of depression, anxiety and externalizing problems showed significant changes in terms of depression and aggression by engaging in works related to nurturing (through eating), regression and relief of aggression through sandplay therapy.

As mentioned above, various studies are in place to improve children's depression and aggression through different therapy methods and mediums. Among them, this study looked at 
Journal of Symbols \& Sandplay Therapy, Vol.9 No.2.

sandplay therapy, a method of psychological therapy created by Dora Kalff who was inspired by Margaret Lowenfeld's World Technique. As sandplay therapy builds on Jung's theory that people have an innate tendency for self-healing with the right conditions provided in their unconscious (Noh \& Hwang, 1998), we believed that it would have a significant therapeutic effect for children in today's society where family's childcare functioning is diminishing and thus it has become increasingly difficult to expect parental help in the effort to improve nurturing environment.

Despite its short history, sandplay therapy has been the topic of many researches especially beginning from 2000s. Aside from the study of Seo (2013) mentioned earlier, other studies discovered that sandplay therapy is effective in reducing depression in the elderly (Jang, 2010), and also adults with ADHD (Kim, 2010). There are also multiple other researches confirming sandplay therapy's effect on reducing aggression, e.g., the study of Ban and Woo (2013) discovered that sandplay therapy reduced aggression in children who are at risk of family disintegration.

Despite an increasing number of studies on the effect of sandplay therapy, not many of them satisfy its essential therapeutic principle: An individual, non-directed therapy centered on the client, allowing the client's dynamics to be expressed freely. To achieve the objective of a study, there is surely a need to come up with a unified program for the participants. But a sandplay therapy that is pre-designed by the researcher and thus guides the participant in a certain way is bound to limit the therapy's potential for self-healing dynamics. The study of Lee (2011) observed how ego-development stages were shown differently in individual and group sandplay therapy based on participants' gender. The study of Lee (2010) also identified differences in the symbols used according to one's age and gender. When looking at these findings, sandplay therapy conducted under a pre-set program would have its limit in respecting and appreciating the unique characteristics of each child and hence would not be able to maximize the unique therapeutic effect of sandplay therapy.

Based on the actualizing tendency - an innate tendency for self-healing given the right conditions in the unconscious - asserted by Jung, sandplay therapy helps clients manifest their inner power (Noh \& Hwang, 1998). Since sandplay therapy focuses on the child's ability to 
manifest his or her inner strengths, rather than on external elements such as parent's nurturing attitude, it can be an effective national-level intervention tool in helping children have a healthier emotional state, even in today's society where family's childcare functioning is diminishing. The client-centered sandplay therapy, in particular, provides individualized counseling conditions in which children can display his or her dynamics in a highly free manner. For these reasons, we can infer that the client-centered sandplay therapy has a significant therapeutic value.

\section{ПI. Research method}

\section{A. Research Design}

This research is a quasi-experiment in which the researcher uses convenience sampling to select study participants. Both a pretest and a posttest were done to the experimental group and the control group. The limitation of a quasi-experiment is that the small number of samples does not allow random assignment. Thus the research has to be designed with caution for the sake of reliability and validity. Moreover, quantitative research alone is not sufficient to fully comprehend the effect of an intervention on children, who have limited capacity for text comprehension and expression. There is especially the risk of not being able to fully reflect the child's emotional state due to social desirability bias. Thus, in case of a quasi-experiment related to making counseling intervention on children and look into its effect, it is more rational to design the research to include both quantitative and qualitative elements so as to reduce potential risks.

\section{B. Client-Centered Sandplay Therapy Program}

The role of the therapist in sandplay therapy is not to lead or give directions, but to support the process of provide a "free and protected space" (Kalff, 1980). In other words, the researcher needs to provide a safe environment with minimum intervention so that the child's 
Journal of Symbols \& Sandplay Therapy, Vol.9 No.2.

dynamics would be expressed freely. Many times, however, therapy programs are designed to provide equal treatment to each child, but such design poses the danger of possibly damage the essence of sandplay therapy. This study therefore did not provide a set program so as to allow children to do sandplay therapy at their own pace.

There is, however, the need to unify the researcher's intervention in order to secure internal validity. Therefore, among six stages developed by Boik and Goodwin (2000) formation of world, experience and rearrangement, treatment, photograph, transference and disintegration - researcher intervention in five stages except "disintegration" was unified. Disintegration was excluded so as to connect the images created by each participant from one session to the next, and thereby maximize the therapeutic effect during the limited number of sessions: 12 including the pretest and posttest. Even with unified researcher intervention, the time spent for each stage and the method of conduct were entirely decided by the adult. This made sure to minimize any damages done to client-centered, individual therapy conditions due to unified researcher intervention.

\section{Research Participants and Data Collection}

Child participants of this study were volunteers from two community child centers in the city of Seoul. The study randomly assigned the participants to the experimental group and the control group. There were a total of 11 participants, 7 boys and 4 girls, aged from 8 to 11. Children who took part in this study are from dual-earner households, families who depend on the national basic livelihood security system, multi-cultural families and grandparent families.

Prior to the research, the participants and their guardians were informed of the following on ethical grounds: research objective and purpose, research process, and the fact that the research will be written as part of the researcher's thesis for master's degree. The researcher also explained that all information related to the participants including photographs and audio data, will be used solely for research purposes and discarded once the research is terminated. Their real names would also be replaced with difference names. The participants are also free to drop out of the program at any time they want. The researcher provided a written document containing the aforementioned statements to the guardians, and the guardians 
provided a written consent to the researcher.

In the quantitative study, pretests and posttests were done on the experimental and control groups. Pretest was conducted during the first sessions of the experimental and control groups. Afterwards, 10 sessions of client-centered sandplay therapy were provided from session 2 to session 10. Then during session 12, posttest was conducted for both groups. Measurement tools used during the pretest and posttest are depression scale and aggression scale.

In the qualitative study, Sentence Completion Test (SCT) and House-Tree-Person Test were conducted during pretest and posttest. After each session, changes observed in sandpictures were analyzed and changes observed in the children were noted. After the termination of the program, the researcher held an interview with social workers who take care of the participants so as to see changes observed by a third person.

Therapy rooms were located within a 10-minute walking distance from each community child centers. The rooms were equipped with plenty of figures and sand trays, and also had easy access to water so as to enable participants to work with wet sand tray.

Considering the purpose of this study, parent interviews were not done for all participants. Parent interview were conducted after the posttest only in case the guardians wished to do so, for the sake of research ethics. The control group was provided with 12 sessions of free sandplay therapy and also parent interviews in case the guardians wanted to do so, for the sake of research ethics.

Photos of sandpictures created by the participants were taken after each session. Verbal and nonverbal responses shown by the participants in the therapy room were both recorded and noted, and were transcribed by hand on the day the therapy took place. Qualitative data was analyzed jointly with a level 2 sandplay therapist who is a member of the Korean Society of Sandplay Therapy (KSST) with 5 years of experience. The outcomes of the analysis and the therapy sessions were reviewed by a KSST supervisor who is certified by the International Society of Sandplay Therapy (ISST). A joint analysis with another therapist and supervision can help a researcher obtain valuable qualitative data. It can also reduce any transmitter effect that might occur when the therapy is administered directly by the researcher, which can have a positive impact in terms of the internal validity. 
Journal of Symbols \& Sandplay Therapy, Vol.9 No.2.

\section{Research Procedure}

\section{1) Preliminary study}

To find rooms for supplementation in terms of the research design, a preliminary study in which 10 sandplay sessions were provided to 7 children from July to September 2017. The preliminary study revealed many limitations: (1) 10 sessions was not enough for a child's dynamics to be manifested, (2) the children misinterpreted the items in different scales due to their limited capacity for text comprehension and expression, and/or it was difficult to trust the test results as they were biased by social desirability, (3) a parent meeting was difficult to schedule in cases where the child is from a dual-income household or a multi-cultural family in which the parent have difficulty in communicating in Korean, and (4) parents refused to come for a meeting in order to hide their insufficient nurturing capacity and, in one case, took the child out of the program.

\section{2) Actual study}

Twelve children from two community child centers in Seoul volunteered to take part in the program. Seven were assigned to the experimental group and five to the control group, in a random manner. However, the pretest result revealed that one child in the experimental group showed symptoms of psychological abnormality and hence the researcher suggested that the child drops out of the program and go see a doctor. Ultimately, there were six children in the experimental group and five in the control group. A total of 12 sessions of client-centered sandplay therapy was given twice a week for six weeks, with each session lasting for 40 minutes.

After the preliminary study, the researcher decided not to have an intake interview and a parent meeting as parents of these children did not have time to take part in them. This is natural considering the fact that most children in community child centers are from dual-earner households, grandparent families or families with negative nurturing attitude. Such decision helps maintain an equal environment for the participants, without the intervention of external various such as changes in parents' nurturing attitude, and thus can possibly have the effect of securing internal validity for the research. 


\section{E. Measurement Tools}

\section{1) Depression index}

To measure depression in children, this study administered Children's Depression Inventory (CDI), a scale developed by Kovacs (1982) using the Beck Depression Inventory (BDI) of 1967 for adults as a model. To be more specific, CDI used in this study was adapted by Cho and Lee (1990) to befit children in Korea. Used for those aged from 7 to 17, CDI is 27-item, self-report questionnaire through which children are asked to select one out of three statements that best describes them within the past two weeks. The scores range from 0 to 2 for each statement, and higher total score indicates higher level of depression. According to Cho and Lee, the Korean version CDI had test-retest reliability of .82, split-half reliability of .71, and internal consistency coefficient pf .88. Among 27 items, this study analyzed 26 items, excluding one that hampers reliability, and the resulting Cronbach's alpha was .74 .

\section{2) Aggression index}

The aggression index used in this study adapted and combined two scales: the Buss-Durkee Hostility Inventory (1957) adapted by Noh (1983), and the Buss - Perry Aggression Questionnaire (1992) adapted by Jeong (1995) and further supplemented by Shim (2000). This 30-item scale is divided into five domains: physical aggression, indirect aggression, verbal aggression, agitation and negativity. In this research however, all the domains were united into one category: aggression. The items are scored on a 5-point Likert scale, and the scoring of these items is reversed. Higher scores indicate higher level of aggression. The reliability of this scale was confirmed in study of Shim (2000), in which the Cronbach's alpha was 90. Out of the 30 items, this study excluded 4 items that hamper reliability when conducting analysis, and the resulting Cronbach's alpha was .92.

\section{3) Sentence Completion Test}

The Sentence Completion Test (SCT) is a projective technique in which the subject is asked to finish a sentence for which the first word or words are supplied. The test shows a child's attitude across four areas: family, sex, interpersonal relationship and self-concept (Choi, 
Journal of Symbols \& Sandplay Therapy, Vol.9 No.2.

2010). SCT was first used by Ebbinghaus (1897) to measure intelligence. Its clinical efficiency was later proven by experimental and experimental researches conducted by many researchers like Stein (1947) and Carter (1947). Today, the most popular is the Sack's SCT. SCT administered in this study consisted of 33 items covering five areas - self-understanding, interpersonal relationship, parent-child relationship, affect and life - which are appropriate for children in elementary school level. This test was used with an aim to supplement the shortcomings of other scales that do not fully reflect children's emotions, a problem caused by children's limited capacity for text comprehension and expression.

\section{4) House-Tree-Person Test}

The study utilized the House-Tree-Person Test (HTP), developed by John Buck (1948) and further advanced by Hammer and Koppize (1969). HTP asks the test taker to use a pencil to draw pictures, respectively, of a house, a tree, and a person, which are neutral stimuli. Then, questions are asked about the drawings which help what meanings they hold personally for the test taker. Because HTP was conducted along with other tests, the researcher asked only one open-ended question considering children's limited level of concentration: "Feel free to make a story about this drawing." The test was used with the purpose of comprehending a child's emotional study that may not be manifested in other scales due to the limited capacity for text comprehension and expression or social desirability bias.

\section{F. Data Analysis}

\section{1) Quantitative data analysis}

Data found through the study were analyzed using SPSS 24.0. First, frequency and elementary statistics were calculated in order to gain an understanding of the response distribution in terms of the participants' general characteristics. Second, the Cronbach's alpha coefficient method was used to analyze the reliability of scales on depression and aggression. Third, a homogeneity test was done to verify whether the pretest results of the experimental group and the control group in terms of aggression and depression are homogenous. The Mann-Whitney U-test was used for the homogeneity test. Fourth, the Wilcoxon signed rank 
test was conducted on pretest-posttest changes in order to verify the experimental effect of a client-centered sandplay therapy for each group. As for the hypothesis test, the significance level was set at $\mathrm{p}<.10$, which is widely used in the field of social science (Lee, 2009).

\section{2) Qualitative data analysis}

Qualitative data was collected through SCT and HTP. Among questions in SCT, only those who are related to the items in the depression and aggression scales were examined. In HTP, the research identified elements that could possibly reveal a child's depression or aggression based on materials provided by Choi (2010), who organized the hypotheses for interpreting the meanings of the drawings provided by Machover (1951) and Levy (1958). Post-therapy analysis on changes observed in children's aggression and depression was based on related statements acquired through non-structured interview with the children. Third-person observations on changes in children's depression and aggression were obtained through related statements by social workers at the community child centers. In addition, the study analyzed Dora Kalff's three stages of ego development - vegetative-animal, fighting, and adaptation to the collective - apparent in children's sandpictures based on the Jang's identification of the characteristics of each stage (2017).

\section{Research result and interpretation}

\section{A. The Effect of Client-Centered Sandplay Therapy on Child's Depression and Aggression}

1) Analysis of quantitative data and its findings

a. Homogeneity test of the pretest depression and aggression levels in the experimental group and the control group

At the beginning of the program, a homogeneity test was conducted to see whether there are differences between the two groups in terms of their depression and aggression levels. The outcome of the test is outlines in Table 1. Homogeneity test was done through the 
Journal of Symbols \& Sandplay Therapy, Vol.9 No.2.

Mann-Whitney U-test. There was not a significant difference between the two groups in terms of depression level $(\mathrm{Z}=-.82, \mathrm{p}>.10)$ and aggression level $(\mathrm{Z}=-.64, \mathrm{p}>.10)$, and hence the two groups were homogenous.

Table 1. Homogeneity test of the pretest depression and aggression levels

\begin{tabular}{lcccccccc}
\hline \multirow{2}{*}{ Measurement tool } & \multicolumn{2}{c}{ Experimental $(\mathrm{n}=6)$} & \multicolumn{2}{c}{ Control $(\mathrm{n}=5)$} & $\mathrm{Z}$ & $\mathrm{Z}$ & $p$ \\
\cline { 2 - 6 } & \multicolumn{2}{c}{ Mean rank } & Rank sum & Mean rank & Rank sum & & & \\
\hline Depression (Pretest) & 6.83 & 41.00 & 5.00 & 25.00 & 10.00 & -.82 & .41 \\
\hline Aggression (Pretest) & 6.67 & 40.00 & 5.20 & 26.00 & 11.00 & -.64 & .52 \\
\hline$* p<.10$ & & & & & & &
\end{tabular}

b. Pretest-posttest differences in depression for the experimental and control groups.

Table 2. Pretest-posttest differences in depression

\begin{tabular}{|c|c|c|c|c|c|c|c|c|c|}
\hline \multirow{2}{*}{ Group } & \multicolumn{2}{|c|}{ Pretest } & \multicolumn{2}{|c|}{ Posttest } & \multicolumn{2}{|c|}{ Pretest-Posttest } & \multirow{2}{*}{ W } & \multirow{2}{*}{$\mathrm{Z}$} & \multirow{2}{*}{$p$} \\
\hline & M & SD & M & SD & M & SD & & & \\
\hline Experimental $(n=6)$ & 16.00 & 8.63 & 8.83 & 4.31 & 7.17 & 5.98 & 15.00 & $1.56^{*}$ & .06 \\
\hline Control $(n=5)$ & 13.00 & 5.10 & 12.80 & 4.38 & .20 & 1.10 & 9.00 & -.80 & .78 \\
\hline
\end{tabular}

Table 2 is the outcome of a Wilcoxon signed rank test that was done to examine the pretest-posttest difference in depression in both the experimental group and the control group. While there was no significant difference in the control group $(\mathrm{Z}=-.80, \mathrm{p}>.10)$, a significant difference was observed in the experimental group $(\mathrm{Z}=1.56, \mathrm{p}<.10)$. In case of the control group, there was a 0.20 point difference in the mean score; the mean score of pretest was 13.00 and that of posttest was 12.80. In case of the experimental group, there was a 7.17 point difference in the mean score; the mean score of pretest was 16.0 and that of posttest was 8.83, showing a significant reduction in the aggression level. In other words, depression level in children was reduced significantly after client-centered sandplay therapy. 
Table 3 is the outcome of a Wilcoxon signed rank test that was done to examine the pretest-posttest difference in aggression in both the experimental group and the control group. Although the control group showed no significant difference $(Z=-1.24, p>.10)$, the experimental groups showed a significant difference $(\mathrm{Z}=1.32, \mathrm{p}<.10)$. In case of the control group, there was a 0.80 point difference in the mean score; the mean score of pretest was 51.80 and that of posttest was 51.00. In case of the experimental group, there was a 13.83 point difference in the mean score; the mean score of pretest was 59.67 and that of posttest was 45.83, showing a significant reduction in the aggression level. In other words, aggression level in children was reduced significantly after client-centered sandplay therapy.

Table 3. Pretest-posttest differences in aggression

\begin{tabular}{|c|c|c|c|c|c|c|c|c|c|}
\hline \multirow{2}{*}{ Group } & \multicolumn{2}{|c|}{ Pretest } & \multicolumn{2}{|c|}{ Posttest } & \multicolumn{2}{|c|}{ Pretest-Posttest } & \multirow{2}{*}{ W } & \multirow{2}{*}{$\mathrm{Z}$} & \multirow{2}{*}{$p$} \\
\hline & $\mathrm{M}$ & SD & M & $\mathrm{SD}$ & M & $\mathrm{SD}$ & & & \\
\hline Experimental $(n=6)$ & 59.67 & 21.49 & 45.83 & 13.17 & 13.83 & 20.60 & 19.00 & $1.32^{*}$ & .09 \\
\hline Control $(n=5)$ & 51.80 & 12.28 & 51.00 & 9.77 & .80 & 7.16 & 8.50 & -1.24 & .89 \\
\hline
\end{tabular}

\section{2) Analysis of qualitative data and its findings}

Elements that indicate changes in depression and aggression were identified in the SCT and the HTP of the control group. However, no such elements were found in the tests of the experimental group. Changes in the experimental group in terms of depression and aggression are shown in Table 4.

This research did not put emphasis on obtaining verbal responses from the children by, for example, asking questions. It did, however, analyze spontaneous verbal expressions and behaviors, which found that children expressed their changes related to their depression and aggression through verbal comments or behaviors. Also, non-structured interviews with social workers at the two community child centers that were conducted after the program finished also revealed changes in the children's depression and aggression from a third-person viewpoint, which is summarized in Table 5. 
Journal of Symbols \& Sandplay Therapy, Vol.9 No.2.

Table 4. Changes in depression and aggression in the experimental group observed through SCT and HTP

\begin{tabular}{|c|c|c|c|c|}
\hline \multirow{2}{*}{ Child } & \multicolumn{2}{|c|}{ SCT } & \multicolumn{2}{|c|}{ HTP } \\
\hline & Pretest & Posttest & Pretest & Posttest \\
\hline $\begin{array}{c}\text { F/Aged } 8 \\
\text { Kim }\end{array}$ & $\begin{array}{l}\text { 27. I can't get good } \\
\text { grades }\end{array}$ & $\begin{array}{l}\text { 27. I can't get good } \\
\text { grades because I don't } \\
\text { study. }\end{array}$ & $\begin{array}{l}\text { Pointy tree branches } \\
\text { and roots }\end{array}$ & Softer tree branches \\
\hline \multirow{3}{*}{$\begin{array}{c}\text { F/Aged } 8 \\
\text { Min }\end{array}$} & $\begin{array}{l}\text { 3. I want to have a lot } \\
\text { of friends. }\end{array}$ & $\begin{array}{l}\text { 3. I have a lot of } \\
\text { friends }\end{array}$ & $\begin{array}{l}\text { All persons are of a } \\
\text { single gender }\end{array}$ & $\begin{array}{l}\text { There are persons of } \\
\text { both genders }\end{array}$ \\
\hline & $\begin{array}{l}\text { 12. The people I hate } \\
\text { the most are Kim OO } \\
\text { and Yang OO. }\end{array}$ & $\begin{array}{l}\text { 12. There is no one } \\
\text { that I hate the most. }\end{array}$ & $\begin{array}{l}\text { Weak pencil pressure } \\
\text { when drawing persons }\end{array}$ & $\begin{array}{l}\text { Same pencil pressure } \\
\text { for house, tree and } \\
\text { person }\end{array}$ \\
\hline & $\begin{array}{l}\text { 27. I neither hate nor } \\
\text { like studying }\end{array}$ & 27. I study very hard. & $\begin{array}{l}\text { A woman wearing a } \\
\text { headband with sharp, } \\
\text { spiky horns }\end{array}$ & $\begin{array}{l}\text { A woman wearing a } \\
\text { plain headband }\end{array}$ \\
\hline $\begin{array}{l}\text { M/Aged } 8 \\
\text { Park }\end{array}$ & $\begin{array}{l}\text { Answered "I don't } \\
\text { know" in } 23 \text { items }\end{array}$ & $\begin{array}{l}\text { Answered "I don't } \\
\text { know" in } 3 \text { items }\end{array}$ & $\begin{array}{l}\text { Size of the tree: } 1 / 5 \\
\text { of an A4 paper }\end{array}$ & $\begin{array}{l}\text { Size of the tree: } 2 / 3 \\
\text { of an A4 paper }\end{array}$ \\
\hline $\begin{array}{l}\text { M/Aged } 11 \\
\quad \text { Song }\end{array}$ & $\begin{array}{l}\text { 22. One of my } \\
\text { shortcomings is that I } \\
\text { get mentally weak } \\
\text { when playing soccer. }\end{array}$ & $\begin{array}{l}22 . \text { One of my } \\
\text { shortcomings is that I } \\
\text { become overly engrossed } \\
\text { while playing soccer. }\end{array}$ & $\begin{array}{l}\text { The branches were } \\
\text { too thin compared to } \\
\text { the thickness of the } \\
\text { trunk }\end{array}$ & $\begin{array}{l}\text { Both the trunk and } \\
\text { the branches were } \\
\text { thick }\end{array}$ \\
\hline $\begin{array}{l}\text { F/Aged } 10 \\
\text { Lee }\end{array}$ & $\begin{array}{l}\text { 20. I sometimes don't } \\
\text { know. } \\
\text { 27. I'm a so-so student } \\
\text { (in terms of grades). }\end{array}$ & $\begin{array}{l}\text { 20. I sometimes feel } \\
\text { good. } \\
\text { 27. I'm a good student } \\
\text { (in terms of grades). }\end{array}$ & $\begin{array}{l}\text { The branches were } \\
\text { short and too thin } \\
\text { compared to the } \\
\text { thickness of the trunk }\end{array}$ & $\begin{array}{l}\text { The trunk was thick, } \\
\text { and the branches } \\
\text { were long and thick }\end{array}$ \\
\hline $\begin{array}{l}\text { M/Aged } 10 \\
\text { Jeong }\end{array}$ & $\begin{array}{l}\text { 31. If I could have my } \\
\text { wishes granted, my first } \\
\text { wish is to earn money. } \\
\text { My second wish is to } \\
\text { buy a big house. My } \\
\text { third wish is to have a } \\
\text { swimming pool. }\end{array}$ & $\begin{array}{l}\text { 31. If I could have my } \\
\text { wishes granted, my first } \\
\text { wish is to have a lot of } \\
\text { money. My second wish } \\
\text { is for my grandmother } \\
\text { to become healthier. } \\
\text { My third wish is to } \\
\text { have a lot of friends }\end{array}$ & $\begin{array}{l}\text { Drew an apartment } \\
\text { with a pointy-looking } \\
\text { attachment building } \\
\text { that took up } 2 / 3 \text { of } \\
\text { the paper }\end{array}$ & $\begin{array}{l}\text { Drew a house which } \\
\text { took up } 1 / 5 \text { of the } \\
\text { paper }\end{array}$ \\
\hline & $\begin{array}{l}\text { 33. If I could become } \\
\text { an animal, I want to } \\
\text { be a crocodile. Because } \\
\text { it's ferocious. }\end{array}$ & $\begin{array}{l}\text { 33. If I could become } \\
\text { an animal, I want to } \\
\text { be the deer because } \\
\text { they have amazing } \\
\text { antlers. }\end{array}$ & Drew three knotholes & No knotholes \\
\hline
\end{tabular}


Soo Kyung Kwak - Mia Seo / The Effect of Client-centered Sandplay Therapy on the Depression, Aggression and Ego Development Stage of Children in a Community Child Center

Table 5. Changes in depression and aggression in the experimental group based on the reports of the children and social workers

\begin{tabular}{|c|c|c|}
\hline Child & Self-report and behavior & Social workers' report \\
\hline & At the beginning of therapy, Kim reported that she & Her shoulder-shrugging tic disappeared. \\
\hline $\begin{array}{c}\text { F/Aged } 8 \\
\text { Kim }\end{array}$ & $\begin{array}{l}\text { hates her younger sibling for crying too loudly and } \\
\text { giving her mother a hard time. Afterwards, } \\
\text { however, she repeatedly talked about how cute her } \\
\text { younger sibling is. }\end{array}$ & $\begin{array}{l}\text { She used to intentionally give cold shoulders } \\
\text { to her peers who wanted to become close } \\
\text { to her. But recently, her relationship with } \\
\text { her peers showed an overall improvement. }\end{array}$ \\
\hline \multirow[t]{2}{*}{$\begin{array}{c}\text { F/Aged } 8 \\
\text { Min }\end{array}$} & $\begin{array}{l}\text { Min felt that her older sister would hit her if she } \\
\text { did not share the cake she got as a present and } \\
\text { therefore didn't want to go home. But later she } \\
\text { came up with the solution to write her name on } \\
\text { the cake box and tell her sister not to take the } \\
\text { cake. }\end{array}$ & $\begin{array}{l}\text { Min had only one friend and therefore } \\
\text { participated only in activities that the friend } \\
\text { took part in. However, she later took part } \\
\text { in all activities with enthusiasm. Even after } \\
\text { the friend moved away, Min made new } \\
\text { friends. }\end{array}$ \\
\hline & $\begin{array}{l}\text { Towards the end of therapy, Min remembered } \\
\text { hitting her male peers quite often and said she felt } \\
\text { rather embarrassed by the memory. }\end{array}$ & $\begin{array}{l}\text { She used to lie and act pretentions, e.g., } \\
\text { telling people she went on an overseas trip } \\
\text { when she didn't. But she no longer displays } \\
\text { such behaviors. }\end{array}$ \\
\hline \multirow{2}{*}{$\begin{array}{l}\text { M/Aged } 8 \\
\text { Park }\end{array}$} & $\begin{array}{l}\text { At the beginning of therapy, Park didn't want the } \\
\text { therapist to look at his sandpicture and pushed the } \\
\text { therapist's chair away. But halfway into the process, } \\
\text { he arranged the figures while conversing with the } \\
\text { therapist. }\end{array}$ & $\begin{array}{l}\text { Park used to disregard younger kids. But } \\
\text { recently, he plays with younger kids who } \\
\text { are new to the community child center. }\end{array}$ \\
\hline & $\begin{array}{l}\text { When his mom called him to eat while he played } \\
\text { video games, he didn't listen. But now he listens } \\
\text { well because he realized that his mom must be } \\
\text { tired from work. }\end{array}$ & $\begin{array}{l}\text { He often didn't show up at the center and } \\
\text { intentionally avoided my phone calls. But } \\
\text { these days, if he's going to be absence he } \\
\text { tells the center in advance. }\end{array}$ \\
\hline \multirow[t]{2}{*}{$\begin{array}{l}\text { M/Aged } 11 \\
\quad \text { Song }\end{array}$} & $\begin{array}{l}\text { Song used to reject solving problems in his } \\
\text { workbook at the community child center. But now } \\
\text { he feels that it's better to do them, even if he } \\
\text { does them half-heartedly. }\end{array}$ & $\begin{array}{l}\text { He cried when he felt that he couldn't } \\
\text { finish the given assignment in time. But } \\
\text { with improved concentration, he's now able } \\
\text { to finish the assignments faster. Plus, he's } \\
\text { learned say no to things that he doesn't } \\
\text { want to do. }\end{array}$ \\
\hline & $\begin{array}{l}\text { He has learned that getting angry and getting into } \\
\text { an argument with his peers while playing soccer } \\
\text { actually makes him lose the game. So now he tries } \\
\text { not to get into arguments even when he's angry. }\end{array}$ & $\begin{array}{l}\text { During class, Song just sat in his seat and } \\
\text { pouted the whole time, which spoiled the } \\
\text { classroom atmosphere. But now he takes } \\
\text { active part in all classroom activities. }\end{array}$ \\
\hline
\end{tabular}


Journal of Symbols \& Sandplay Therapy, Vol.9 No.2.

Table 5. Changes in depression and aggression in the experimental group based on the reports of the children and social workers

(continued)

\begin{tabular}{|c|c|c|}
\hline Child & Self-report and behavior & Social workers' report \\
\hline $\begin{array}{l}\text { M/Aged } 11 \\
\quad \text { Song }\end{array}$ & $\begin{array}{l}\text { His father always wanted him to read and recite } \\
\text { Bible verses but he didn't listen. But now he feelings } \\
\text { like doing them little by little. }\end{array}$ & $\begin{array}{l}\text { He used to curse to himself when things } \\
\text { didn't go well while playing soccer, but has } \\
\text { recently stopped doing so. }\end{array}$ \\
\hline \multirow{3}{*}{$\begin{array}{l}\text { F/Aged } 10 \\
\text { Lee }\end{array}$} & \multirow{3}{*}{$\begin{array}{l}\text { Lee reported that it feels as if she's become a bit } \\
\text { nicer these days. }\end{array}$} & $\begin{array}{l}\text { Despite her excellent athletic ability, Lee was } \\
\text { always unenthusiastic about physical activities } \\
\text { and often disappeared in the middle. But } \\
\text { recently, she takes part in these activities until } \\
\text { the end. }\end{array}$ \\
\hline & & $\begin{array}{l}\text { Lee used to ostracize some friends in her peer } \\
\text { group, but recently has stopped doing so. }\end{array}$ \\
\hline & & $\begin{array}{l}\text { When she didn't want to take part in } \\
\text { activities at the center, she challenged her } \\
\text { teacher as to why she should do so. But } \\
\text { recently, she has stopped doing so. }\end{array}$ \\
\hline \multirow{2}{*}{$\begin{array}{l}\text { M/Aged } 10 \\
\text { Jeong }\end{array}$} & $\begin{array}{l}\text { At the beginning of therapy, he said that he's good } \\
\text { at nothing. But towards the end, he said that he's } \\
\text { good at art. }\end{array}$ & $\begin{array}{l}\text { When he was given assignments, he always } \\
\text { claimed that he doesn't understand and didn't } \\
\text { do them. But recently, he's trying to give his } \\
\text { best effort. }\end{array}$ \\
\hline & $\begin{array}{l}\text { Jeong said he wants to smack OO, who often hits } \\
\text { him, with a piece of brick. At the time of therapy's } \\
\text { termination, however, he said he doesn't hate OO as } \\
\text { much. }\end{array}$ & $\begin{array}{l}\text { Jeong used expletives that are inappropriate for } \\
\text { children, but has stopped doing so. }\end{array}$ \\
\hline
\end{tabular}

\section{B. Changes in the ego-development stage manifested in the sandpicture}

Although the sand tray in Figure 1 is full, there is an absence of relationship as indicated by a woman figure who is alone and an empty space near her. But the presence of a bridge brings in the possibility for a relationship and possibly suggesting an early phase of the socialization stage. The lack of relationship shown in Figure 1 is also present in Figure 2 and Figure 3. In Figure 4, however, we see union of the opposites represented by a man and a woman as well as a pair of swans, and the presence of an island inside a pond that is in the shape of a mandala. Union of the opposites or the mandala is a symbol of the socialization 
stage, the last stage among the three development stages suggested by Kalff.

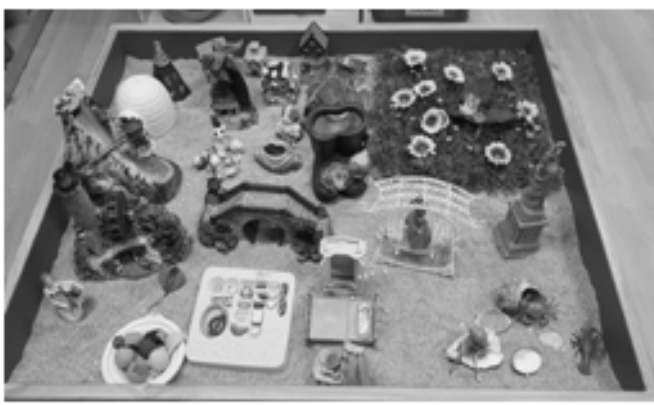

Figure 1. Kim's sandpicture in session 2

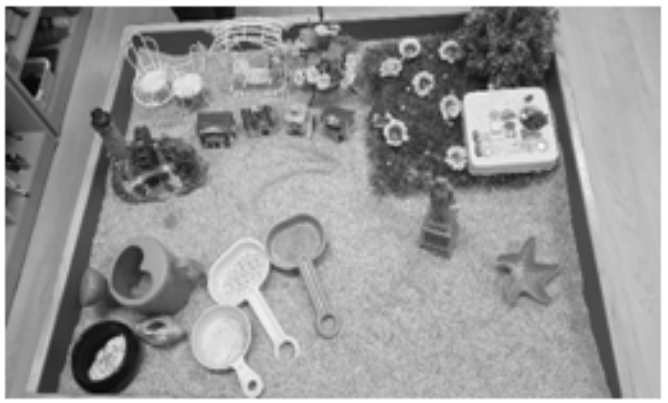

Figure 3. Kim's sandpicture in session 4

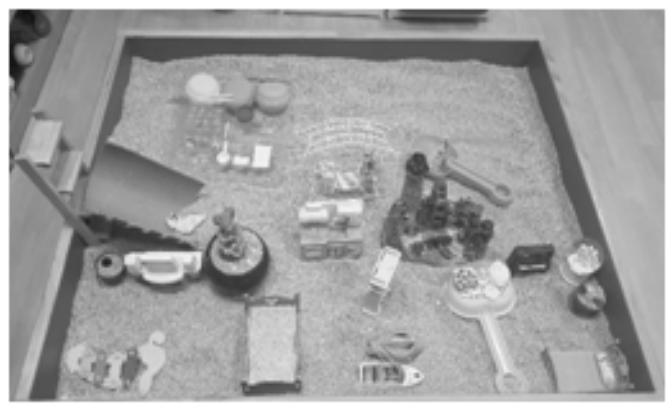

Figure 2. Kim's sandpicture in session 3

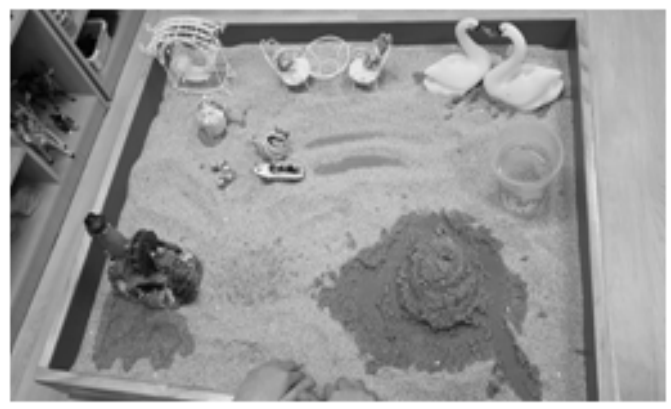

Figure 4. Kim's sandpicture in session 6

The presence of large animals and fruit figures puts Figure 5 into the category of the vegetative-animal stage. Figure 8 is a combination of the fighting stage, suggested by the fact that different groups are fighting against each other, and the socialization stage, which is represented by the presence of houses, a hospital, a port and a village. What's especially noticeable in Figure 8 is the port, from which one can embark on a journey to find the ego. Despite Figure 7's image of destruction in which most of the figures are either broken down or hurt, we could see that the construction of this port began in session 3 (Figure 6). Figure 8 could indicate a possibility for the beginning of a deeper inner development. 


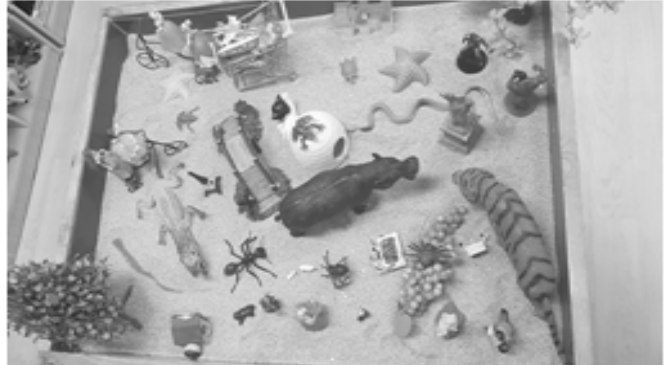

Figure 5. Min's sandpicture in session 2

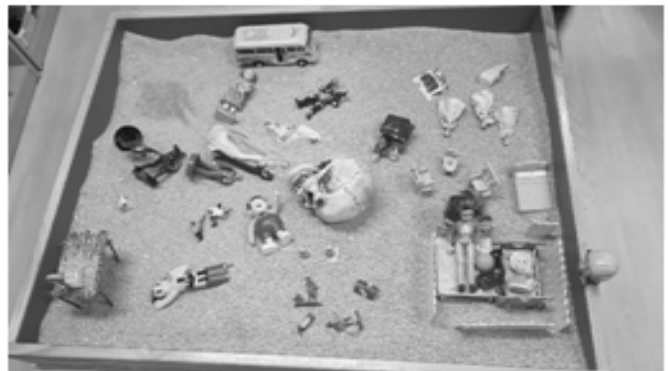

Figure 7. Min's sandpicture in session 4

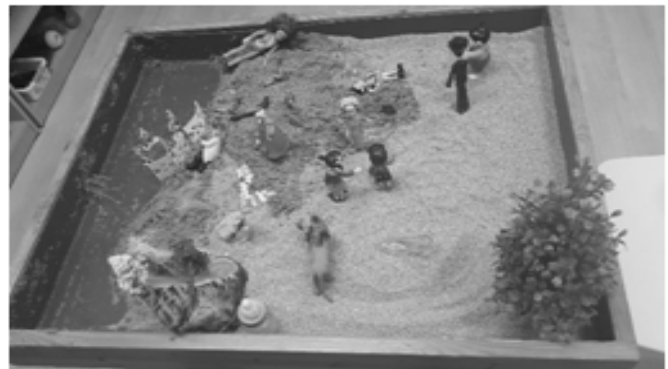

Figure 6. Min's sandpicture in session 3

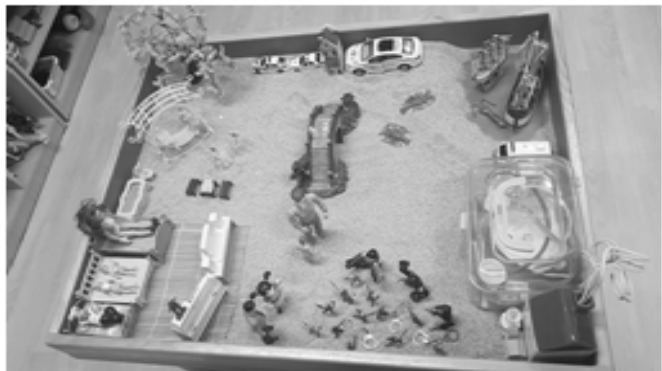

Figure 8. Min's sandpicture in session 6

With skeleton and ghost figures scattered on the sand, Figure 9 could represent the vegetative-animal stage in a state of chaos. Figure 10 looked like the fighting stage at an undifferentiated state while there seemed to be a differentiation in Figure 11, between dinosaurs and animation/movie characters. During session 9 (Figure 12), the child created a picture on the floor in which a man and a woman are sitting across a table from each other. The formation resembles a mandala, and thus can be interpreted as the potential to reach the stage of socialization, or adaptation to the collective, where there is the union of the opposites.

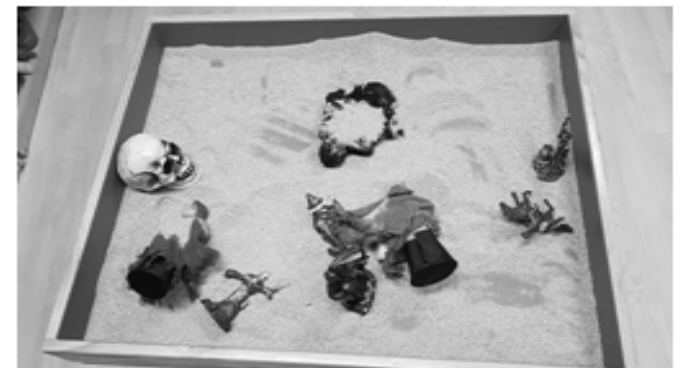

Figure 9. Park's sandpicture in session 2

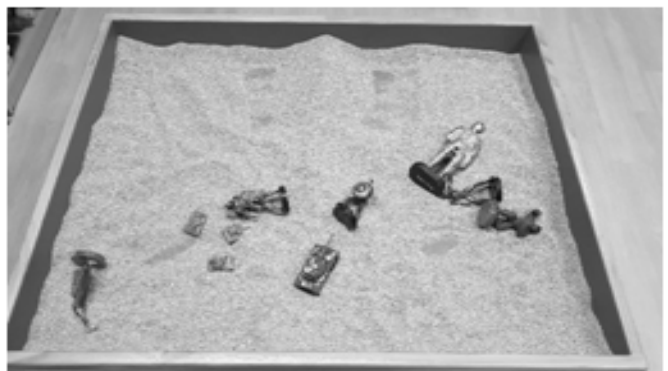

Figure 10. Park's sandpicture in session 4 


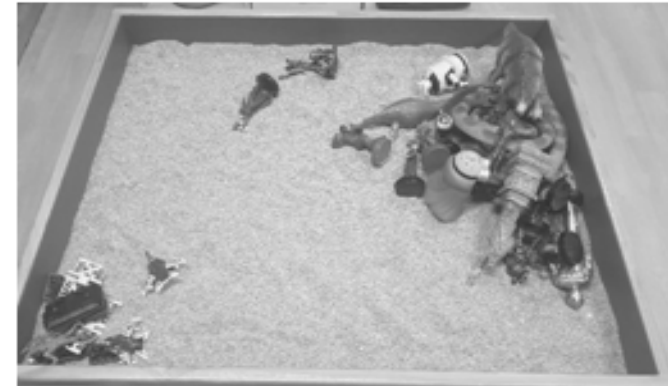

Figure 11. Park's sandpicture in session 9

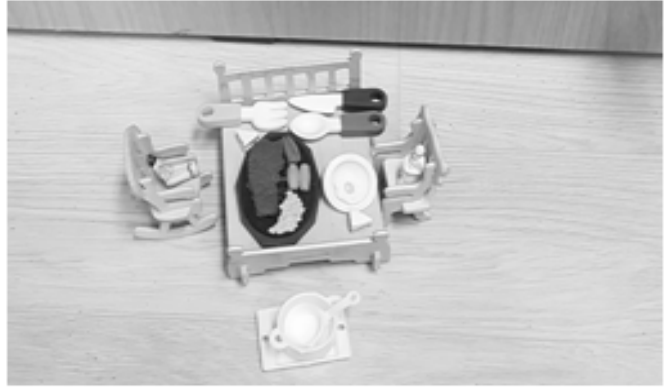

Figure 12. Park's floor picture in session 9

At first, Song complained of feeling uncomfortable using figures and minimized his contact with sand. But halfway through the process, he touched the sand with enthusiasm and used many figures to represent the fighting stage in multiple pictures. Figure 14 showed a fight in which there were differentiated opposing forces. Figure 15 depicted a fight in which Song was present. Figure 16 showed a more sophisticated state of the fighting stage with a clear leader on each side.

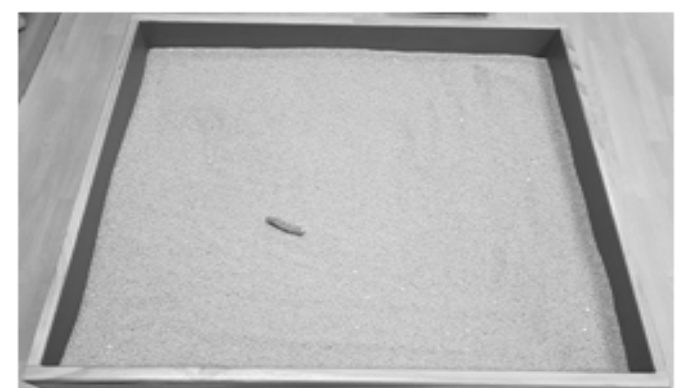

Figure 13. Song's sandpicture in session 2

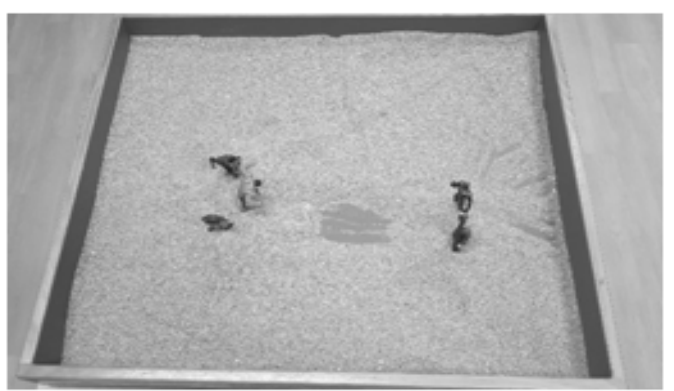

Figure 15. Song's sandpicture in session 7

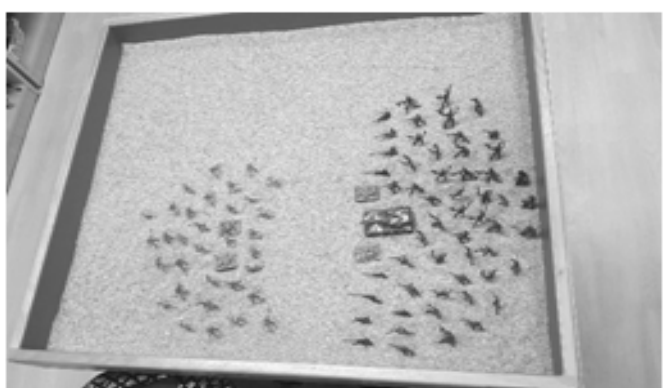

Figure 14. Song's sandpicture in session 6

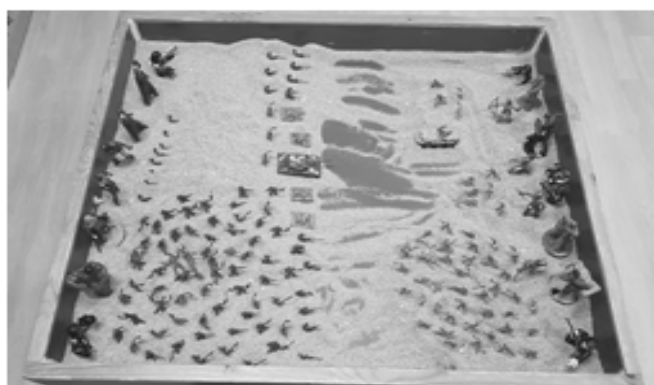

Figure 16. Song's sandpicture in session 10 
Journal of Symbols \& Sandplay Therapy, Vol.9 No.2.

Lee hardly used figures in her/his sandtray throughout the entire process. For most of the therapy time, she touched the wet sand and used only a few figures. In session 7 (Figure 20), however, he/she created a scene of marriage between two swans, a union of the opposites which could be a symbol of the socialization stage.

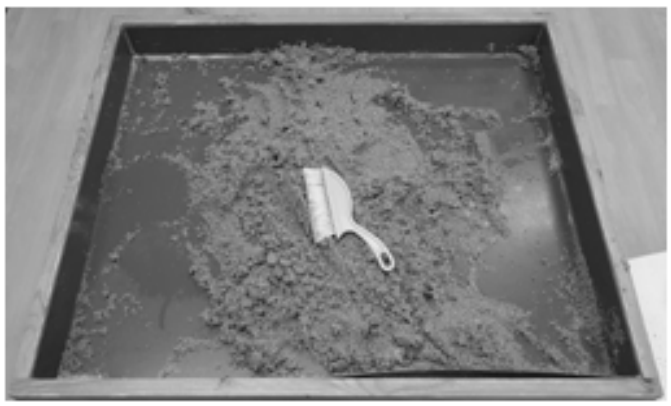

Figure 17. Lee's sandpicture in session 3

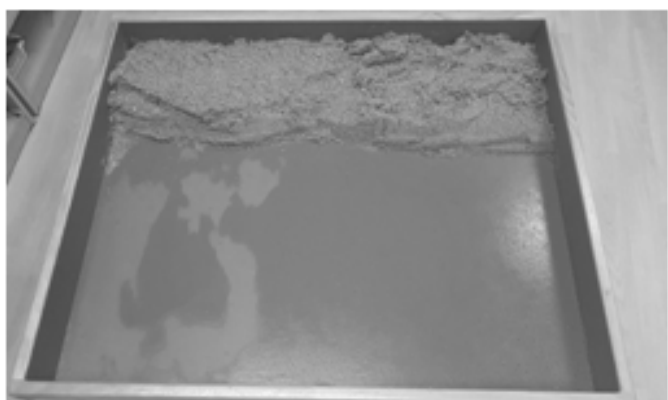

Figure 19. Lee's sandpicture in session 5

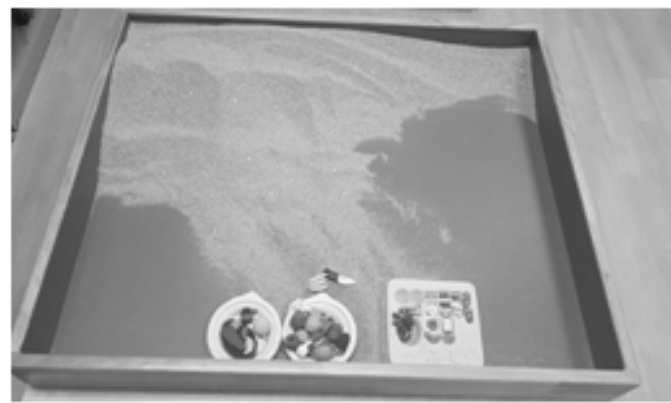

Figure 18. Lee's sandpicture in session 4

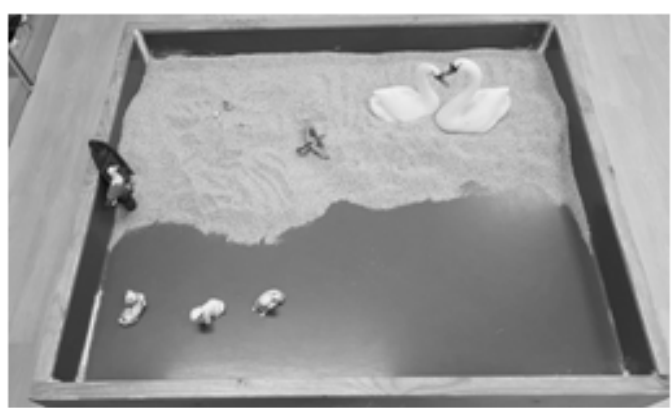

Figure 20. Lee's sandpicture in session 7

Jeong's first sandpicture (Figure 21) represented the third stage of ego development or the socialization stage through the construction of a village and reclamation of farmland. Although he attempted to build another village in session 3 (Figure 22), he failed to do so as he was not able to control his aggression which was represented by a large animal figure in the picture. But in session 6 (Figure 23), a baby dinosaur was born out of an egg, which could be a symbol of a psychological rebirth. The presence of a village and a zoo in the next sandpicture (Figure 24) shows that Jeong was able to control his aggression in an appropriate and safe manner, and thus the picture represents the socialization stage where there is an adaptation to the collective. 

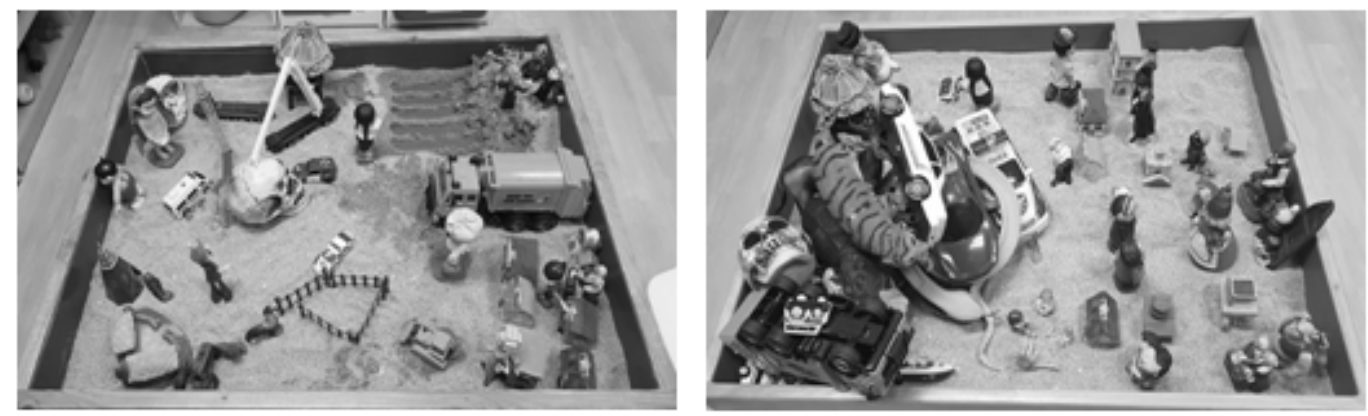

Figure 21. Jeong's sandpicture in session 2 Figure 22. Jeong's sandpicture in session 3
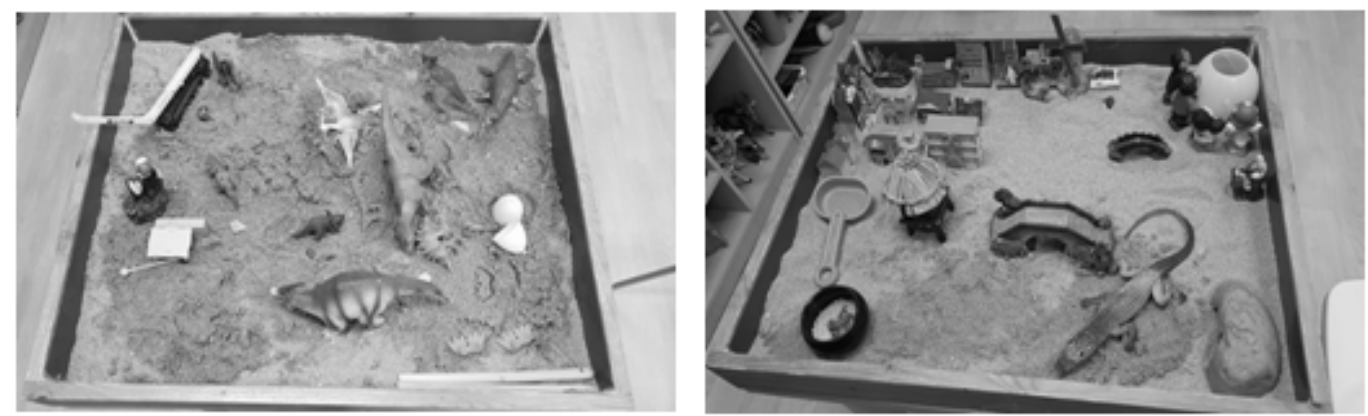

Figure 23. Jeong's sandpicture in session 6 Figure 24. Jeong's sandpicture in session 7

\section{Discussion and conclusion}

This research was conducted with an aim to observe the effect of client-centered sandplay therapy on reducing depression and aggression of children in community child centers. In order to secure a condition in which children's dynamics would easily be manifested, an individual, client-centered sandplay therapy was offered to children in community child centers for a total of 12 sessions. There were six children in the experimental group and five in the control group. Quantitative data was collected through the use of scales measuring depression and aggression before and after therapy. Qualitative data was collected through SCT and HTP as well as the report made by social workers at the centers. Changes exhibited in children's sandpictures were analyzed based on Dora Kalff's ego-development stages.

Based on its findings, the study would like to discuss the following: First, there was a 
Journal of Symbols \& Sandplay Therapy, Vol.9 No.2.

significant difference in children's depression before and after the client-centered sandplay therapy; children's depression was significantly reduced after sandplay therapy. Even in SCT and HTP, multiple items supported that participants' depression level was reduced. In addition, although the research did not try to obtain verbal responses from children by, for instance, asking questions, children spontaneously expressed changes they experienced with regard to their depression through verbal means or behaviors. Many of the social workers also reported changes observed in the children's depression. Such findings coincide with the study of Park (2008), which found that sandplay therapy reduces depression and anxiety in children.

Second, there was a significant difference in children's aggression before and after the client-centered sandplay therapy; children's aggression was significantly reduced after sandplay therapy. Both SCT and HTP provided multiple qualitative data that supports reduced aggression level in the participants. In addition, although the research did not try to obtain verbal responses from children by, for instance, asking questions, children spontaneously expressed changes they experienced with regard to their aggression through verbal means or behaviors. Many of the social workers also reported changes observed in the children's aggression. Such findings are in line with the study of Ban \& Woo (2013), which reported that sandplay therapy reduces externalizing problems such as delinquency and aggression in children at risk of family integration.

Third, an analysis of Kalff's ego-development stages manifested in the sandpictures revealed that although all participants went through the three stages, the starting point and the speed of progress were different for each participant. Such outcome is in sync with the study of Lee (2011), which found that there is a gender different in terms of the ego-development stages expressed in individual and group sandplay therapies, and also the study of Lee (2010), which witnessed differences in symbols used depending on different age groups and gender. That there are differences in each children in terms of their ego development expressed through sandplay therapy indicates that a structured sandplay therapy or a group sandplay therapy may be ineffective in helping individual child manifest their dynamics. It appears that a client-centered sandplay therapy, which allows clients to freely express their ego development, would be more effective in activating the self-healing tendency in children. 
Based on the findings above, this paper would like to elaborate a few limitations of this study and make recommendations for future studies. First, the study sample was limited to 11 children in two community child centers, which makes is difficult to generalize the study's outcome. Hence there is a need to conduct another research with a bigger sample so as to re-evaluate the effect of client-centered sandplay therapy on depression and aggression in children.

Second, because only 12 sessions of therapy was conducted, there were some cases in which the process had to come to an end without reaching the third stage of ego development, or the socialization stage, suggested by Kalff. An individual's ego development occurs repeatedly at a deeper dimension in the form of a spiral, and thus future studies ought to provide enough number of sessions so as to see what happens at a deeper level of development.

Third, the participants of this research are children who attend a community child center. But we must bear in mind children in community child centers are actually protected within the government support system. It is therefore recommended that later studies provide client-centered sandplay therapy to children from double-income families or multicultural families who do not have the privilege of being supported by a community child center.

Despite the limitations mentioned above, the research is meaningful for the following reasons: First, it was able to verify that client-centered sandplay therapy is effective in reducing depression and aggression in children through quantitative and qualitative data. Second, it showed that each child has a different starting point and speed when it comes to reaching Kalff's third stage of ego development. Third, in order to minimize not only the limitations posed by a quasi-experiment in which a small sample does not allow randomization but also the impact of children's limited capacity for text comprehension and expression or social desirability bias on validity and reliability, the study adopted a mixed design in which both quantitative and qualitative data are used.

The meaningful findings of this study lead to a deduction that a client-centered sandplay therapy, which activates the self-healing tendency in children by allowing their dynamics to be manifested freely, has a greater therapeutic value than a structured, 
Journal of Symbols \& Sandplay Therapy, Vol.9 No.2.

therapist-centered sandplay therapy in which the therapist determines the speed and direction. In conclusion, administering a client-centered sandplay therapy to children with unsupportive parents in terms of improving nurturing environment will facilitate their self-healing energy and hence produce an effective outcome.

\section{References}

Achenbach, T. M. (1991). Manual of the child behavior checklist. Burlington, VT: University of Vermont.

Ban, P-J., \& Woo, J-Y. (2013). An analysis of changes and themes in delinquency and aggression of children in crisis of family disorganization through sandplay therapy. The Korean Association Rehabilitation Psychology, 20(1), 65-100.

Beck, A. T. (1967). Depression: Clinical, experimental and theoretical aspects. PA: University of Pennsylvania.

Boik, B. L., \& Goodwin, E. A. (2000). Sandplay therapy-a step-by-step manual for psychotherapists of diverse orientations. Seoul: Hakjisa. (Korean trans.)

Chang, J-W. (2010). A study on the effect of sandplay therapy on the quality of mental life of the elderly. (Master's thesis, Sangmyung University, Seoul, Korea).

Choi, H-J. (2017). The influence of art therapy to reduction of anxiety and aggressiveness of parental divorce children. (Master's thesis, Daejeon University, Daejeon, Korea).

Choi, J-Y. (2010). Understanding of psychological assessment. Seoul: Sigmapress.

Cho, S-C., \& Lee, Y-S. (1990). Development of the Korean form of the Kovacs' children's depression inventory. Journal of the Korean Neuropsychiatric Association, 29(4), 948-959.

Headquarters of Community Child Center (2017). Report of Statistical Survey of Community Child Center in Korea as of December, 2016. Retrieved from https://www.icareinfo.go.kr/main.do Jang, M-K. (2017). Analytical psychological sandplay therapy. Seoul: Hakjisa.

Kalff, D. (1980). Sandplay: a psychotherapeutic approach to the psyche. Cloverdale, CA: Temenos Press. 
Kim, C-N., \& Lee, E-Y. (2012). Effects of group forgiveness counselling program on the aggression and interpersonal relationship for 6th grade elementary school student. The Journal of Korean Society of Maternal and Child Health, 16(1), 32-43.

Kim, M-Y. (2008). Effects of cognitive-behavioral education program on the depression and cognitive errors of cbildren. (Master's thesis, Chinju National University, Chinju, Korea).

Kim, S-S. (2008). A study on the factors affecting the psychosocial development of poor children. (Doctoral thesis, Seoul National University, Seoul, Korea).

Kim, T-Y. (2010). The effect of sandplay therapy on ADHD adults' depression and anxiety. Journal of Symbols and Sandplay Therapy, 1(1), 15-40.

Kwon, S-M. (2013). Contemporary abnormal psychology. Seoul: Hakjisa.

Lee, E-C. (2011). Effects of sandplay on children's ego development stage, self-esteem, and sociality: based on gender difference. (Master's thesis, Gachon University, Seongnam, Korea).

Lee, J-S. (2009). The public administration dictionary. Goyang: Daeyoungmunhwasa.

Lee, M-S. (2005). Depression 119. Seoul: Galim.

Lee, M-S. (2010). Children's use of symbols by age and gender in sand play pictures. (Doctoral thesis, Myongji University, Seoul, Korea).

Lee, Y-K. (2015). The influence of cbildren's anger on depression and aggression: moderating effects of anger coping style and self-esteem. (Doctoral thesis, Catholic University, Seoul, Korea).

Lim, D-Y., \& Kim, Y-M. (2010). The effects of narrative therapy group counseling on children's dysfunctional beliefs and aggression. Journal of Korean Association of Child Studies, 31(1), 125-136.

Nam, S-H., \& Baek, Y-M. (2013). The effects of cognitive-behavior group counseling program on aggressiveness and self-esteem of elementary school student. The Korean Journal of Rehabilitation Psychology, 20(3), 545-564.

Noh, C-H., \& Hwang, H-H. (1998). Sandplay therapy. Seoul: Dong-suh.

Park, E-A. (2011). Effects of a sandtray on depression of the adolescent victims of the family violence. Journal of Korean Arts Psychotherapy Association, 7(2), 31-57.

Park, J-Y. (2008). The effect of the sandplay therapy about an infant who has symptoms, the depression, anxiety, and the withdrawal behavior. (Master's thesis, Chonnam National University, 
Journal of Symbols \& Sandplay Therapy, Vol.9 No.2.

Gwangju, Korea).

Seo, S-H. (2013). A case study on sandplay therapy of 8-year-old child having depression, anxiety, and externalizing tendency. Journal of Sandplay Therapy, 9(1), 1-39.

Sim, S-W. (2000). The relationship among the children's perceived social support, self-esteem and aggression. (Master's thesis, Ewha Woman's University, Seoul, Korea).

Sohn, E-H. (2011). The effects of self-confrontation method program on the depression and self-esteem of children. (Master's thesis, Kyungpook National University, Daegu, Korea).

Yoon, J-Y. (2009). The effects of group game play therapy on depressive children's depression and life satisfaction. (Master's thesis, Myongii University, Seoul, Korea).

Received : October 24, 2018

Revised : December 8, 2018

Accepted : December 15, 2018 